\title{
The Baroque Tragedy of the Roman Jesuits: Flavia and Beyond*
}

\author{
Blair Hoxby
}

Between 1556 and 1773, when the order was suppressed by order of the Pope, the Jesuits may have produced as many as 100,000 'solemn tragedies.' They staged these at the seven hundred and fifty universities and colleges that they opened during those years, some located next to seats of power such as Rome, Paris, Munich, and Vienna, where they entertained monarchs and princes of the church and had access to the finest composers, musicians, and dancing masters of the day; others scattered as far afield as Brazil, Mexico, India, and the Philippines. The global reach of the Jesuits was already apparent to the Puritan William Prynne in 1633 when, in his giant anti-theatrical treatise Histrio-mastix,

* I am grateful to Sarah Janda and Nolan Epstein for their research assistance, to Leon Hopper, s.J., for providing access to a copy of Selectce Patrum Societatis Jesu Tragoedice, and to Jan Bloemendal and Nigel Smith for comments on an earlier draft.

1 For the estimate, which is based on colleges performing an average of two plays per year, see W.J. McCabe, s.J., An Introduction to Jesuit Tragedy, ed. Louis J. Oldani (St. Louis: Institute of Jesuit Sources, 1983), pp. 36, 47. In 1555, colleges averaged fewer than one per year, but in exceptional cases, such as Billom, France in 1557 , a college might produce as many as eight. Performance schedules became more regular with time. For additional details on the first decade of productions, see Mario Fois, S.J., 'La retorica nella pedagogia Ignaziana prime attuazioni teatrali e possibile modelli', in Maria Chiabò and Federico Doglio (eds.), I Gesuiti e i primordi del teatro barocco in Europa (Rome: Centro studi sul teatro medioevale e rinascimentale, 1995), pp. 57-99, esp. pp. 84-90. The diversity of the Jesuit repertoire is stressed in the same volume by Nigel Griffin, 'Plautus Castigatus: Rome, Portugal, and Jesuit Drama Texts'. It is also demonstrated by Jan Bloemendal and Howard B. Norland (eds.), NeoLatin Drama and Theatre in Early Modern Europe (Leiden and Boston: Brill, 2013); see esp. Jean-Frédéric Chevalier, 'Neo-Latin Theatre in Italy' and 'Jesuit Neo-Latin Drama in France' and Fidel Rädle, 'Jesuit Theatre in Germany, Austria and Switzerland', pp. 25-101, 185-292, 415469. Good introductions to Jesuit theater include McCabe, An Introduction to Jesuit Tragedy; Bruna Filippi, 'The Orator's Performance: Gesture, Word, and Image in Theatre at the Collegio Romano', in John W. O'Malley et al. (eds), The Jesuits II: Cultures, Sciences, and the Arts, 15401773 (Toronto: University of Toronto Press, 2006), pp. 512-529; and Blair Hoxby, What Was Tragedy? Theory and the Early Modern Canon (Oxford: Oxford University Press, 2015), ch. 5. Also see (in Italian) Chiabò and Doglio (eds.), I gesuiti e i primordi del teatro barocco.

(C) BLAIR HOXBY, 2016 | DOI: 10.1163/9789004323421_008

This is an open access article distributed under the terms of the CC-BY-NC License. 
he deplored the 'histrionicall' Society of Jesus for bringing their interludes and stage plays 'to their Indian Proselites. ${ }^{2}$ Considered as a global phenomenon, the theatrical repertoire of the Jesuits displays a tremendous variety of form and content because the Society of Jesus was always ready to make concessions to local traditions, customs, and resources. Nevertheless, the tragedies produced at the Collegio Romano enjoyed a special authority because its faculty authored the official plan for Jesuit education known as the Ratio studiorum (Plan of Studies), which was issued in successive versions in 1586, 1591, and 1599, and because their example served as the surest guide to its proper implementation. ${ }^{3}$

Before Bernardino Stefonio (156o-1620) took up his pen, the most ambitious theatrical production that the Collegio Romano had mounted was Stefano Tucci's 1573 Christus judex (Christ the Judge). ${ }^{4}$ The signal achievement of Stefonio, who directed Tucci's play, was to recast this tradition of sacred representation in a form suggested by the examples of Euripides and Seneca, authors who were achieving new salience in the Jesuit curriculum with the promulgation of the Ratio studiorum and with the publication of Martin Delrio's edition of all the remains of Latin tragedy (1593-1595). By noting when Stoic doctrine clashed with Christian dogma, Delrio's formidable edition not only made Seneca 'safe' for the classroom, it suggested how Counter-Reformation dramatists could revise Seneca for their own purposes. ${ }^{5}$

2 William Prynne, Histrio-mastix, The Players Scourge, or, Actors Tragaedie, Divided into Two Parts (London: E[dward] A[llde, Augustine Mathewes, Thomas Cotes] and W[illiam] I[ones] for Michael Sparke, 1633), p. 117 .

3 Ignatius of Loyola, The Constitutions of the Society of Jesus, transl., introd. and comm. George E. Ganns, S.J. (St. Louis: The Institute of Jesuit Sources, 1970), par. 4., c. 7, n. 2, Declaratio C.

4 On Tucci, see Benedetto Soldati, Il Collegio Mamertino e le origini del teatro gesuitico, con l'aggiunta di notizie inedite sulla drammatica conventuale messinese nei secolixVI., XVII., XVIII. e con la pubblicazione della Giuditta del P. Tuccio (Turin: E. Loescher, 1908). For selections in Latin with Italian transl., see Stefano Tucci, Christus nascens; Christus patiens; Christus iudex: tragoediae (Rome: Institutum historicum Societatis Iesu, 2011). For previous accounts of theater at the Collegio Romano, see Daniela Quarta, 'La drammaturgia Gesuita nel Collegio Romano: Dalla tragedia di soggetto biblico al dramma martirologico (1564-1614)' and Bruna Filippi, 'Il teatro al Collegio Romano, dal testo drammatico al contesto scenico', both in Chiabò and Doglio (eds.), I gesuiti e i primordi del teatro barocco, pp. 119-16o, 161-182; Bruna Filippi, 'The Orator's Performance: Gesture, Word, and Image in Theatre at the Collegio Romano', in John W. O'Malley, S.J. a.o. (eds), The Jesuits II: Cultures, Sciences, and the Arts 1540-1773 (Toronto, etc.: University of Toronto Press, 2006); Marc Fumaroli, Héros et orateurs: Rhétoriques et dramaturgie cornéliennes (Genève: Droz, 1996), pp. 138-170; Chevalier, 'NeoLatin Theatre in Italy', pp. 72-84; and Hoxby, What Was Tragedy?, ch. 5 .

5 Martin Antonio Delrio, Martini Antonii Delrii ex Societate Iesu Syntagma tragoediae lati- 
Stefonio responded to the stimulus of Delrio's edition and to his duties as professor of rhetoric by writing three original tragedies: Santa Symphorosa (1593), which dramatizes the martyrdom of a Christian widow and her sons under the emperor Hadrian; Crispus (1597), which casts a son of the emperor Constantine in the role of Hippolytus, falsely accused of rape by his stepmother and rashly condemned to death by his father; and Flavia (160o), which represents the martyrdom of three Christians of the imperial family during the reign of Domitian. If Crispus was 'an event within the bounds of the Jesuit pedagogical empire' ('un événement interne à l' empire pédagogique jésuite'), as Marc Fumaroli observes, 'Flavia acquired a truly Roman Catholic dimension' ('la Flavia acquiert une dimension vraiment catholique romaine'), not least because it was performed during Carnival of the Holy Year declared by Clement VIII in 1600 and because the pope's nephew, Cardinale Aldobrandini, contributed to its spectacular staging. ${ }^{6}$ An anonymous diarist from the Collegio Romano records its success:

Quest'anno se è fatta la tragedia della Flavia o di S. Clemente Flavio, si è recitata quatro volte con molto plauso e concorso. La spesa delle scene, palco e musica, l'ha fatta il Cardinale Aldobrandini, e la tragedia è stato composta dal P. Bernardino Stefonio. La prima volte ha durato quasi dieci ore, poi si è abbreviata acciò non recasse fastidio. Ciò non ostante, la varietà e novità delle cose, le mostre navali, i bastimenti, e sopra tutto l'eccelenza de recitanti e il numero degl'attori han dato gran varietà, a han cagionato gran diletto. ${ }^{7}$

(This year was produced the tragedy of Flavia, or of St. Clement Flavius, which was performed four times with much applause and large audiences. The theater, stage, and music were arranged by Cardinal Aldobran-

nae: in tres partes distinctum (Antwerp: ex Officina Plantiniana, apud Viduam [et] Ioannem Moretum, 1593-1595). On the edition, see Maturin Dréano, Humanisme chrétien: La tragédie latine commentée pour les chrétiens du XVIe siècle (Paris: Editions Beauchesne, 1936); Roland G. Mayer, 'Personata Stoa: Neostoicism and Senecan Tragedy', Journal of the Warburg and Courtauld Institutes 57 (1994), 151-174, esp. pp. 159-167; and Jan Machielsen, Martin Delrio, Demonology and Scholarship in the Counter-Reformation (Oxford: Oxford University Press, 2015), pp. 137-203.

6 Fumaroli, Héros et orateurs, p. 146.

7 Quoted in Riccardo G. Villoslada, s.J., Storia del Collegio Romano dal suo inizio (1551) alla soppressione della Compagnia di Gesù (1773) (Rome: Apud Aedes Universitatis Gregorianae, 1954), p. 166; Villoslada summarizes the plot on pp. 162-165. 
dini, and the tragedy was composed by Father Bernardino Stefonio. The first time lasted almost ten hours, then it was abridged so that it might not be tedious. This notwithstanding, the variety and novelty of the matter, the naval displays, ships, and above all the excellence of the declamation and the number of the actors produced a great variety and occasioned great delight.)

The success of Flavia was not ephemeral. The Collegio Romano restaged Flavia and issued it in print in 1621, a few months after the poet's death. ${ }^{8}$ The authority of its example was then cemented by Stefonio's successors as professors of rhetoric at the Collegio Romano, Tarquinio Galluzzi (1573-1649) and Alessandro Donati (1584-1640). Galluzzi included a commentary on tragedy in his 1621 Virgilianae vindicationes \& commentarij tres de tragoedia, comoedia, elegia (Vindications of Virgil and Three Commentaries on Tragedy, Comedy, and Elegy) and mounted a polemical defense of his teacher's tragedies in his 1633 Rinovazione dell'antica tragedia e Difesa del Crispo (Renovation of Ancient Tragedy and Defense of 'Crispus'). Donati won fame in his day for his 1622 tragedy Pirimalus Celiani princeps, performed to celebrate the canonizations of Sts. Ignatius of Loyola and Francis Xavier, and his 1629 tragedy Suevia, a brutal analysis of sibling rivalry that dramatizes the attempted assassination of Conrad IV, the son of the German Emperor Frederick II Hohenstaufen, in the aftermath of a military campaign against Naples. But Donati features in this essay chiefly as the author of the 1631 Ars poetica (Art of Poetry), one of the most lucid treatises on epic and tragedy published in the seventeenth century. ${ }^{9}$

8 Bernardino Stefonio, FLAVIA, Tragoedia Bernardini Stephonii E Societate Iesu Diu antea, vivente Autore, flagitata: posthuma nunc tandem prodit (Rome: Apud Haeredem Bartholomei Zannetii, 1621). I, however, have used the text printed in Selectce Patrum Societatis Jesu Tragoedice (Antwerp: Ioan Cnobbarvm, 1634); henceforth cited parenthetically in the text.

9 On Pirimalus, see Bruna Filippi, 'Le spectacle des idoles dans le théâtre de conversion jésuite (xvire siècle)', in Ralph Dekoninck and Myriam Watthee-Delmotte (eds.), L'Idole dans l'imaginaire occidental (Paris: L'Harmattan, 2005), pp. 167-180; id., Il Teatro degli argomenti: Gli scenari seicenteschi del teatro gesuitico romano (Rome: Institutum Historicum S.I., 2001), pp. 104-112; on Suevia, see Jean-Frédéric Chevalier, 'Neo-Latin Drama in Italy', in Bloemendal and Norland, Neo-Latin Drama and Theatre in Early Modern Europe, pp. 80-83; on the Ars poetica, sive Institutionum artis poeticae libri tres (Rome: Faciotti, 1631), see Nienke Tjoelker, Andreas Friz's Letter on Tragedies (ca. 1741-1744) (Leiden and Boston: Brill, 2015), Drama and Theatre in Early Modern Europe, 4, pp. 35-36; Barbara Bauer, "Multimediales Theater": Ansätze zu einer Poetik der Synesthäsie bei den Jesuiten', in Heinrich F. Plett, RenaissancePoetik/Renaissance Poetics (Berlin and New York: De Gruyter, 1994), pp. 197-238, esp. pp. 213215. 
I make Flavia the center-piece of this essay for three reasons: first, because in dramatizing a minor episode in the history of the Church rather than a story drawn from the Old Testament, it illustrates a distinctive contribution of the Jesuits to our tragic repertoire; second, because, as one of the most exuberant theatrical productions of the Counter-Reformation, it invites us to inquire what is implied when we call a tragedy baroque; and third, because, as a drama that brings the pagan and the Christian into collision, striving to arouse not just pity and fear but admiration for those Christian martyrs who, renouncing the carnal world, suffered brutal tortures and perished as a sublime example to the faithful, it demands that we reflect on our most entrenched presuppositions about the nature and ends of tragedy.

\section{Flavia as Sacred Representation}

Flavia is set in the year AD 93, when Domitian was said to have descended into bloody tyranny, exiling the philosophers from Rome, killing some Roman senators and their families, and persecuting the Christians. ${ }^{10}$ As Marc Fumaroli observes, it is structured like a theatrical realization of the Ignatian 'Meditation on Two Standards.'11 This exercise asks us to meditate on two scenes. On the plain of Babylon, we should behold Lucifer atop a great throne of fire and smoke, dispatching his demons over the globe to ensnare men; and on the great plain of Jerusalem, we ought to visualize Christ selecting apostles and disciples to spread his sacred doctrine, instructing them to choose poverty in lieu of riches, the scorn of the world before honor, and humility rather than pride. The spiritual exercise concludes with a colloquy with which we, the exercitents, can appeal to the Virgin Mary to intercede with her Son that he might bestow grace and receive us under his (military) standard. ${ }^{2}$ As the Spiritual Exercises make clear, however, choosing Christ does not depend on a simple election of will; it hangs, too, on a capacity to 'discern spirits', to differentiate

10 Stefonio's primary historical sources besides Philostratus's Life of Apollonius are Suetonius, Life of Domitian, 15.1; Dio Cassius, History of Rome, 67.14; and Eusebius, Ecclesiastical History, 3.17, 28; and the first two volumes of Caesare Baronio, Annales ecclesiastici, 12 vols. (Rome, 1588-1607).

11 Fumaroli, Héros et orateurs, p. 148.

12 Ignatius, Exercitia spiritualia, ed. Iosephus Calveras and Candidus de Dalmases (Rome: Institutum Historicum Societatis Iesu, 1969) Monumenta Historica Societatis Iesu, 100, pp. 135-147 (Second Week, Fourth Day). 
between divine impulsions and demonic solicitations, between true apostles and false prophets. ${ }^{13}$

In Flavia, we are asked to choose between Jesus Christ and Apollonius of Tyana, whom one nineteenth-century study aptly names The Pagan Christ of the Third Century. ${ }^{14}$ Classicists who have tried to pierce through the vortex of romance and polemic that swirls around Apollonius have suggested that he may have lived from about 40A.D. to about 120A.D., traveling among the Greek cities of the Near East, but his chief ancient biographer makes him an exact contemporary of Jesus, saying that he lived from the reign of Tiberius to that of Nerva (ca. 3/4 BC-AD 98). Perhaps he would have slipped into historical obscurity had not the Empress Julia Domna, wife of Septimius Severus, urged Philostratus to undertake that biography. Even if we assume that the notebooks of Damis that she purportedly gave him as source material are a fiction, there is little doubt of the imperial family's interest in Apollonius, for Julia Domna's son Caracalla dedicated a shrine to him in Tyana.

Philostratus's Life, which is the longest biography to survive from the classical world, became entwined with the history of the Church about sixty-five years after its composition when Sossianus Hierocles, an Antiochian adviser to the emperor Diocletian, compared Apollonius to Jesus of Nazareth in an antiChristian tract that he circulated in Palestine and Syria before the persecution of the Christians in $302 \mathrm{~A}$.D. It is not hard to see why the comparison occurred to Sossianus, for Apollonius, like Jesus, was remembered for his sermons and parables. He preserved his virginity, observed a rule of silence for five years,

13 On the rules for the 'discernment of spirits', see Ignatius, Exercitia spiritualia, pp. 313336; Hugo Rahner, Ignatius the Theologian, transl. Michael Barry (New York: Herder and Herder, 1968), pp. 136-180; Jules J. Toner, A Commentary on Saint Ignatius' Rules for the Discernment of Spirits: A Guide to the Principles and Practice (St. Louis: The Institute of Jesuit Sources, 1982); and Marjorie O'Rourke Boyle, 'Angels Black and White: Loyola's Spiritual Discernment in Historical Perspective', Theological Studies 44 (1983), 241257 .

14 Albert Réville, Apollonius of Tyana, the Pagan Christ of the Third Century (London: John Camden Hotten, 1866). On Apollonius, see esp. Maria Dzielska, Apollonius of Tyana in Legend and History (Rome: 'L'Erma' di Bretschneider, 1986) and Jaap-Jan Flinterman, Power, Paideia \& Pythagoreanism: Greek Identity, Conceptions of the Relationship between Philosophers and Monarchs, and Political Ideas in Philostratus' 'Life of Apollonius"' (Amsterdam: J.C. Gieben, 1995), both with earlier bibliography. For the life, see Philostratus: The Life of Apollonius of Tyana, ed. and transl. Christopher P. Jones, 3 vols., Loeb Classical Library (Cambridge, MA and London: Harvard University Press, 2005), henceforth cited parenthetically. 
healed the sick, exorcized demons, defeated vampires, and raised the dead. He claimed to be an incarnation of Proteus the Egyptian, and late in his life, he appeared capable of escaping chains and appearing before his disciples in distant lands. As a sage who had lived in the shrine of Asclepius and learned the secrets of Babylonian magicians, Indian Brahmans, and the Naked Ones of Egypt, he seemed to represent all the occult wisdom and thaumaturgic powers of pagan religion and philosophy.

By comparison, said Hierocles, Jesus Christ was merely a robber and a magician. 'We [pagans] do not think a man who performed such deeds to have been a god', he wrote of Apollonius,

but only a man pleasing to the gods; while [Christians] are led by a few illusions to declare Jesus a god ... While the deeds of Jesus have been exaggerated by Peter, Paul, and people of their stripe-liars, yokels, sorcerers-, the deeds of Apollonius have been recorded by Maximus of Aegae, Damis the philosopher who studied with him, and Philostratus of Athens. All of these reached a very high level of culture and honored truth, and from motives of humanity did not wish the acts of a virtuous man, a friend of the gods, to go unknown. ${ }^{15}$

Although Lactantius (tutor of Constantine's ill-fated son Crispus) conceded the thaumaturgic powers of Apollonius, he believed that they depended on the use of illicit arts. What's more, he argued that because the Jewish prophets had foretold the coming of the Messiah a thousand years before, Jesus had to be more than a mere magician. Indeed he was, according to one common interpretation of Revelation, the Lamb who opened the sealed book of the Old Testament (Rev. 5). Eusebius of Caesarea, author of the first church history, swiftly followed with a lengthier reply that defended the divinity of Jesus and dismissed Apollonius as a common wonder-worker or worse, an instrument of Antichrist. ${ }^{16}$ Despite, or because of, Eusebius's vituperative reply, the cult of

15 Quoted in Eusebius, Reply to Hierocles, 2.2, included in Philostratus: The Life of Apollonius, ed. Jones, vol. 3 .

16 For this background, see Timothy D. Barnes, 'Sossianius Hierocles and the Antecedents of the "Great Persecution"', Harvard Studies in Classical Philology 80 (1976), 239-252; Stephen Benko, 'Pagan Criticism of Christianity during the First Two Centuries A.D.,' in Hildegard Temporini and Wolfgang Haase (eds.), Aufstieg und Niedergang der Römischen Welt, ser. 2, vol. 23.2 (Berlin: Walter de Gruyeter, 1980), 1055-1118; Tomas Hägg, 'Hierocles the Lover of Truth and Eusebius the Sophist', Symbolae Osloenses 67 (1992), 138-150; Jeffrey W. Hargis, Against the Christians: The Rise of Early Anti-Christian Polemic (New York: Peter Lang, 
Apollonius enjoyed a revival in the Greek east: statues and effigies were erected and talismans signed with his name circulated. But the renaissance was a brief one, for in $\mathrm{AD} 313$ all restrictions were lifted from the Christians, and by AD 331, still within Eusebius's lifetime, the temple of Asclepius in Aegaeae had been razed to the ground. The senate of Rome nevertheless continued to harbor conservative, pagan aristocrats, one of whom, Virius Nichomachus Flavianus (ca. 334-394), translated Philostratus's Life of Apollonius of Tyana into Latin in order to erect a standard around which pagans could rally. Thus St. Augustine could still complain that pagans would believe the miracles described in the bible if only they were attributed to Apollonius or Apuleius. ${ }^{17}$

Apollonius's reputation as a false Christ-figure was still so notorious in the Renaissance that publication of the editio princeps of his Life required tact. For the Vatican had launched a concerted campaign against the occult arts, prosecuting humanists such as Pico della Mirandola for their study of magic. Aldus Manutius wisely elected to publish the Life in three parts consisting of the Greek text (1501), a Latin translation of Eusebius's Reply (1502), and Alemano Rinuccino's attractive Latin translation of the Life (1504). The Aldine edition started 'an avalanche of treatises, contributions, and literary works devoted to the prophet of Tyana', who henceforth began to occupy 'much space in Church historiography and in monographs devoted to the history of the early Roman Empire.'18 In Caesare Baronio's Annales ecclesiastici (1588-1607), for example, Apollonius appears as a deceiver, a magician, and an imposter elevated to divine honors by the worst of Roman emperors. Able to be everywhere at once and skilled in the arts of magic, he is ever averse to the Christians. ${ }^{19}$ Yet what made Apollonius the object of so much anxiety among Christian apologists was not his difference from Jesus but his indistinguishability. As Baronio himself concedes, some Christians gave up Christ as a true god once they met Apollonius, and at least one pagan worshipped him in the eclectic company of Christ, Abraham, and Orpheus. Thus the clergyman Edward Berwick was quite right to

1999); and Christopher P. Jones, 'Apollonius of Tyana in Late Antiquity', in Scott F. Johnson (ed.), Greek Literature in Late Antiquity (Aldershot, England and Burlington, vт: Ashgate, 2006), pp. 49-64.

17 Augustine, Epistulae 102, in Saint Augustine, Letters, Volume II (83-130), transl. Sister Wilfrid Parsons (New York: Fathers of the Church, 1953), pp. 171-172.

18 Dzielska, Apollonius of Tyana, p. 197.

19 Caesare Baronio, Annales ecclesiastici; tomus primus, 682E; Annales ecclesiastici; tomus secundus (Venetiis: sumptibus Laurentii Basilii et Antonii Tivani, 1706), 264D1, 271D-E2, 506Al; on Baronio's project in general, see Cyriac K. Pullapilly, Caesar Baronius: CounterReformation Historian (Notre Dame and London: University of Notre Dame Press, 1975). 
be incensed by Edward Gibbon's pithy dismissal of Apollonius in The Decline and Fall of the Roman Empire: 'Apollonius of Tyana was born about the same time as Christ. His life (that of the former) is related in so fabulous a manner by his fanatic disciples, that we are at a loss to discover whether he was a sage, or an imposter. ${ }^{20}$ As Gibbon's parenthetical clarification slyly insinuates, the fabulous nature of the gospels poses the same difficulty in the case of Jesus. Because Flavia is set in 93A.D., some sixty years after the crucifixion of Jesus, the choice that Stefonio's play dramatizes is not between the historical Jesus and Apollonius but between Jesus Christ the co-eternal Son of God, and Lucifer, prince of demons; between the St. John the Evangelist and Cerinthus the gnostic, whom some biblical commentators identified with the Antichrist of 1John 2:22; between Jewish prophecy and the pagan arts of augury, astrology, and thaumaturgy.

In the opening scene of Flavia, the Flamen of Jupiter hails the return of the sun and praises Domitian for promoting to the rank of caesar his nephews Domitian and Vespasian, the sons of Flavius Clemens and Domitilla. As the Flamen consults the sibylline books, a chorus of Roman youths sing Horace's Carmen saeculare to mark the arrival of a new saeculum, or era, in Roman history, precisely 110 years after Caesar Augustus declared Ludi saeculares to celebrate the fifth saeculum of Rome. But the temple is scandalously empty, and Christianity is responsible for this neglect of Rome's gods. In the act's final scene, hemi-choruses of Roman Christians sing a subtly revised version of Horace's Carmen saeculare in which Apollo and Diana yield to Christ and the Virgin Mary as the tutelary gods of Rome. Meanwhile, Apollonius, who has just won his release from prison determines to revenge himself on his persecutor, the Emperor Domitian. Once the scene has changed to present a horrible wasteland, Apollonius performs a hair-raising ritual (modeled chiefly on the scenes of necromancy in Seneca's Medea and Lucan's Pharsalia) to conjure up spirits from Hades. The barking of Cerberus and an eruption of flames forewarn us that the spirits have heard his invocation: Cerberus, the Hydra, the Centaur, the Dragon, the Harpy, and other hellish forms appear on stage. Enjoined to assume more attractive shapes, they transform themselves (behind the cover of a cloud machine) into a troop of sixteen comely Ethiopian youths, well-versed in all the arts of language, song, dance, and arms. In this new guise, they wear

20 Edward Gibbon, Decline and Fall of the Roman Empire [1776-1789], ed. David Womersley, 6 vols. in 3 (London: Allen Lane, the Penguin Press, 1994), 1, p. 315 n. 63. In response, Berwick published the first complete English translation of Philostratus's Life in 1809; see Dzielska, Apollonius of Tyana, pp. 205-206. 
flowing yellow barbarian costumes, Phrygian bracelets, and Sidonian boots. Like the exotic sorcerer who has conjured them up, they embody the strangeness that the play draws into itself.

In Act 2, the tension between Rome's traditional cults and Christianity is heightened, as a priest reveals the beliefs of the Christians to an incredulous Domitian (who orders their persecution) and John the Evangelist arrives in Rome upon the welcome news that the crypto-Christians Domitian and Vespasian are poised to assume the reins of empire. Once in Rome, John immediately encounters and repudiates Apollonius. Yet Apollonius's plot continues to prosper in Act 3, as he wins Domitian's favor with his gift of the Ethiopians, sets Fulvius Valens on the path to insurrection, and begins to prey on the paranoia of the tyrannous Domitian by dropping dark hints of a conspiracy in the palace. In Act 4, the Roman people express their fervent hope for a new golden age under the young caesars, but Apollonius's dark prophecy-that a father and two sons will have to be killed before the palace is safe-prepares us for their fall. In Act 5, the sorcerer-who, we should remember, claimed to be an incarnation of the shape-shifting Proteus-disguises himself as Fulvius Clemens, the father of the two caesars, and in that form tells them of Domitian's unexpected conversion to Christianity. He then instructs them to present the emperor with crosses at their accession ceremony. The results are predictably disastrous. Domitian imprisons their father, and when the sons refuse to sacrifice to Jupiter, he sacrifices them under the supervision of Apollonius, reserving their heads so that he, like Seneca's Atreus, may ask his brother with grizzly satisfaction if he recognizes his own sons. Having so revenged himself on the psyche of Fulvius Clemens, the emperor then decapitates him in full view of the audience. Apollonius consummates his own personal vendetta by presenting the heads of all three martyrs to John the Evangelist, who accepts them as sacred relics.

These events transpire amid an atmosphere of religious uncertainty and controversy, for not only does paganism remain the state religion of Rome, Christianity is still a religion in the making. Indeed, John arrives in Rome fresh from his polemical engagements with Cerinthus, a gnostic and chiliast whose teachings are recorded in Irenaeus's Adversus haereses (Against Heresies) (ca. 180):

Cerinthus, again, a man who was educated in the wisdom of the Egyptians, taught that the world was not made by the primary God, but by a certain Power far separated from him, and at a distance from the Principality who is supreme over the universe, and ignorant of him who is above all. He represented Jesus as having not been born of a virgin, but 
as being the son of Joseph and Mary according to the ordinary course of human generation, while he nevertheless was more righteous, prudent and wise than other men. Moreover, after his baptism, Christ descended upon him in the form of a dove from the Supreme Ruler, and that then he proclaimed the unknown Father, and performed miracles. But at last Christ departed from Jesus, and that then Jesus suffered and rose again, while Christ remained impassible, inasmuch as he was a spiritual being. ${ }^{21}$

In Irenaeus's account, Cerinthus appears to blend gnostic beliefs (that the world was produced by a distinct and inferior Demiourgos, that a spiritual Christ possessed Jesus, and that his ministry consisted of revealing the unknown, Highest God) with beliefs more often associated with Judaism: that Jesus was a natural though righteous man who died and was resurrected. In works dating from $182-188,260$, and $374-376$ respectively, Irenaeus, Victorinus, and Epiphanius of Salamis all advance the opinion that John wrote the Fourth Gospel or passages of his first epistle to refute Cerinthus. ${ }^{22}$ On the other hand, we also find early Christians urging the rejection of the Fourth Gospel and Revelation as the work of Cerinthus, a charge that seventeenth-century commentators still feel compelled to weigh. ${ }^{23}$ In other words, just as Jesus and Apollonius could be all too readily compared, so John and Cerinthus could appear deceptively similar.

21 Irenaeus, Adversus haereses, 1.26.1, transl. in Alexander Roberts and James Donaldson (eds.), The Ante-Nicene Fathers: Translations of the Writings of the Fathers down to A.D. 325, rev. A. Cleveland Cox (Grand Rapids, MI: Wm. B. Eerdmans Publishing Company, 1885).

Martine Dulaey, Victorin de Poetovio: Sur l'Apocalypse et autres écrits (Paris: Cerf, 1997), 11.1; Epiphanius, Panarion, 51.4.1-2; 51.6; 51.12.3-6. For an English translation of selections, see The Panarion of St. Epiphanius, Bishop of Salamis, transl. and ed. Philio R. Amidon, s.J. (New York and Oxford: Oxford University Press, 1990), esp. pp. 87-89.

23 All the ancient accounts of Cerinthus are reviewed in Daniel R. Streett, They Went Out from Us: The Identity of the Opponents of First John (Berlin and New York: De Gruyter, 2011), pp. 53-77. Useful recent accounts include Klauss Wengst, Häresie und Orthodoxie im Spiegel des ersten Johannesbriefes (Güttersloh: Mohn, 1976); Charles E. Hill, 'Cerinthus: Gnostic or Chiliast? A New Solution to an Old Problem', Journal of Early Christian Studies 8 (2000), 135-172; Pamela A. Kinlaw, The Christ is Jesus: Metamorphosis, Possession, and Johannine Christology (Atlanta: Society of Biblical Literature, 2005); Matti Myllykoski, 'Cerinthus', in Antti Marjanen and Petri Luomanen (eds.), A Companion to Second-Century Christian 'Heretics' (Leiden: Brill, 2005), pp. 213-246. To cite just one example, the Calvinist commentator David Pareus, A Commentary upon the Divine Revelation of the Apostle and Evangelist John, transl. Elias Arnold (Amsterdam: C.P., 1644), p. 6, feels the need to defend Revelation against the charge that it was written by Cerinthus. 
In 1546, the Council of Trent adopted the final Catholic position on the matter: Revelation was a canonical book of the bible authored by John the Evangelist. ${ }^{24}$ Thus in Flavia, the points of difference between John and his antagonist are clear. John grumbles that Cerinthus has pulled apart the shining glory of heaven by denying that God and Christ are one. This is in keeping with Irenaeus's suggestion that Cerinthus is the target of John 20:31 ('And these are written, that you may beleeue that Jesus is Christ, the sonne of God') and 1John 2:22 ('Who is a lier but he which denieth that Jesus is not Christ? This is Antichrist which denieth the Father and the Sonne.'). ${ }^{25}$ John explains to his Roman audience that, lest Cerinthus lead anyone into wickedness, he has traced the birth of the Son from the beginning (II.6.1076-1079):

Superiùs ipse exorsus, æterna indico

Principia generis. quippe de DEO DEVS,

De Mente Verbum, Patris exemplum, Patri

Par erat, \& æqui Numinis Numen potens.

II.6.1038-1041

(I myself, beginning farther back, point out the immortal beginnings of his birth. Indeed, God from God, Word from Mind, a model of his Father, He was equal to his Father and, himself divine, was in command of an equal divinity.)

The world had not yet been created when the Son leapt forth as a likeness from the fertile mind of the Father (II.6.1051-1057). The Father and the Son were co-equal as creators, nor did the Father withdraw from his creation: 'Together with the Mind, the Word controls the world's vicissitudes' ('Cùm Mente Verbum temperat mundi vices', II.6.1070). In the fiction of Flavia, John's words provide an unimpeachable provenance for the Nicæno-Constantinopolitan Creed of AD 381. But if they served as a confession of faith for the audience gathered to watch Flavia, they may also have reminded them of the purge that followed the Council of Nicea, a purge that saw bishop Arius exiled, his books burned, and his followers branded enemies of Christ. ${ }^{26}$ Even in the sixteenth and seven-

24 Hubert Jedin, A History of the Council of Trent (London: T. Nelson, 1957-1961), 2, pp. 71-72.

25 The New Testament of Iesus Christ, Translated Faithfully into English (Rheims: Iohn Fogny, 1582), better-known as the Douay-Rheims Bible, henceforth cited parenthetically.

26 For a lucid account of the context, see esp. Philip Schaff, History of the Christian Church [1858-1892], 8 vols. (Peabody, MA: Hendrickson Publishers, 1996), 3, pp. 661-684. 
teenth centuries, Arianism and other forms of Antitrinitarianism continued to appeal to heterodox theologians such as Faustus Socinus.

Not content to furnish a first-century pedigree for the Creed, Flavia also furnishes one for embattled beliefs and practices ranging from the use of vestments, candles, and images in worship (II.3.514-545, II.4.705-710) to the sacrament of the Eucharist. The Protestant view of all these is summed up by Thomas Brightman in his refutation of the Jesuit Robert Bellarmine's account of Revelation: 'al that your worship of Images, invocation of Saincts, adoration of the feighned body in the sacrament, veneration of reliques, and many such like things, is horrible Idolatry, and therefore Apostasie. But idolatry is spiritual whoredome: and therefore as the way of the whorish woman, which eateth, and then wipeth her mouth, and sayth, I have doon no iniquity; Prov. 30. 20. So is the way of Idolators: by no means can they be brought to acknowledge their impiety. ${ }^{27}$ By the time Brightman was writing, he could rely on the research that Matthias Flacius Illyricus (1520-1574) and other Lutheran scholars had compiled in their Ecclesiastica historia, known as the Centuriae Magdeburgenses or Magdeburg Centuries (1559-1574). This massive historical enterprise sought to prove that the Church had fallen away from its primitive simplicity shortly after the death of the first apostles. But an unintended consequence of their project had been to document the antiquity of the very tenets that they wished to reform. Caesare Baronio's response in the Annales ecclesiastici, which he published in twelve volumes from 1588 to 1607 , was to document the earliest appearance of those which the Church wished to preserve and defend. Thus we can find in Baronio's discussion of the Eucharist that, as early as AD106, Saint Ignatius of Antioch wrote letters to the Christians of Rome and Smyrna referring to the bread of God as the flesh of Jesus Christ. Not only Ignatius, 'a disciple of the apostles' ('Apostolorum discipulus)', but Irenaeus, 'an attendant of Policarpus the student of the apostle John' ('Policarpi Ioannis Apostoli discipuli auditor'), and Justin Martyr, 'himself indeed in the vicinity of Apostolic times' ('ipse etiam Apostolorum temporibus vicinus'), are called to bear witness to the apostolic origins of the doctrine of 'transubstantiation' ('transubstantiatum'). ${ }^{28}$

27 Thomas Brightman, A Revelation of the Apocalyps, that is, The Apocalyps of s. Iohn, illustrated with an Analysis \& Scolions: Where the sense is opened by the scripture, \& the events of things foretold, shed by Histories (Amsterdam: Iudocus Hondius \& Hendrick Laurens, 1611), p. 509. For an introduction to Brightman and his context, see Katherine R. Firth, The Apocalyptic Tradition in Reformation Britain, 1530-1645 (Oxford: Oxford University Press, 1979), esp. pp. 161-174, where she also discusses Jesuit interpretations of Revelation. 
In a similar spirit, Flavia describes the celebration of Mass by a priest splendidly attired in a cloak of Phrygian work. He approaches an altar brightly lit by wax candles, set off with mosaics, and graced with a golden cross. The Christians, explains the pagan priest who is recounting this ceremony to Domitian, maintain that there is an efficacy in the words that the priest pronounces over the bread and the wine, that the blood of Christ replaces the wine and the body of Christ replaces the bread (II.3.558-559):

\section{audivit simul}

Arcana verba, fruge depulsâ, simul

Insinuat, astris lapsus, in frugis globum,

Et in liquoris penetrat ejecti locum, Imago facti viva, simulamen necis, Amoris irritamen, exemplum sui. Blanditur oculis, naribus, linguæ color, Odor, saporq́ue panis, ac vini quidem: Vtrumque verè, quisquis hæc credit, negat. Tegumenta tantùm panis, \& vini manent: Quæ citima sensus hominis attingunt levi Specie, sed intus quidquid est, ipse est DEvs, Idem ille CHRIsTvs, quantus æquævo Patri Assidet, honestâ luce præcinctus comas: Quantus rubente tela jaculatur manu, Et nube vectus terga ventorum premit, Sub orbe Cereris tantulo tantus latet. Hoc incruentæ cædis exemplum, vocant Quondam cruentæ cædis imitamen pium.

II.3.571-588

(As soon has he has heard the sacred words, he makes his way with the bread having been pushed aside, into the circle of bread, having glided down from the stars, and he passes into the place of the liquid, which has been cast out, the living image of the deed, an imitation of death, an incitement of love [for him], a model of himself. The color, smell, and taste of the bread and wine caress the eyes, nose, tongue: each he

see 'The Epistle of Ignatius to the Romans', ch. 7 and 'The Epistle of Ignatius to the Smyrnaeans', ch. 7, both in Roberts, Donaldson, and Coxe (eds.), Ante-Nicene Fathers, 1, pp. 76,89 . 
denies, whoever truly believes in this. Only the shells of the bread and wine remain, which, being nearest, touch a man's senses with superficial appearance. But whatever is inside, that is God himself and likewise that Christ, as great as when he sits by the side of his coeval Father, His hair circled with honoring light, as great as when he hurls darts with his ruddy hand and presses on the backs of the winds, conveyed on a cloud, so great is he when he lurks in the little circle of bread. This example of bloodless slaughter they call a pious imitation of that bloody slaughter on another occasion.)

When the Christians consume the Eucharist, they behave like the Maenad when she rages with Bacchus received inside her, wandering the wooded mountains in the gleaming night' ('Qualis Lyæo Mænas accepto furit, | Nemerosa lustrans nocte sublustri juga', II.3.626-627). They become fearless and crave martyrdom (II.3.628-635).

The accounts of Christian worship that circulated in the first centuries were not always so benign: Christians were routinely accused of cannibalism, human sacrifice, and incest, or of what Athenagoras describes colorfully as 'Thyestian feasts [and] Oedipal couplings' (Legatio 3). ${ }^{29}$ What must have made such accusations uncomfortable reading in the sixteenth-century is that Christians did sometimes commit such atrocities. As Michel de Montaigne memorably records, George Sechel, the leader of a peasant revolt, was tortured for three days and then fed to his followers in a bloody parody of Holy Communion that Sechel seems to have entered into, as he atoned for the sins of his followers:

En fin, luy vivant et voyant, on abbreuva de son sang Lucat, son cher frere, et pur le salut duquel il prioit, tirant sur soy toute l' envie de leurs meffaicts; et fit l' on paistre vingt de ses plus favoris Capitaines, deschirans à belles dents sa chair et en engloutissants les morceaux. Le reste du corps et parties du dedans, luy expiré, furent mises bouiller, qu'on fit manger à d'autres de sa suite.

29 See Jean-Pierre Waltzing, 'Le Crime rituel reproché aux chrétiens du IIe siècle', Musée Belge 29 (1925), 209-238; Albert Henrichs, 'Pagan Ritual and the Alleged Crimes of the Early Christians: A Reconsideration', in Patrick Granfield and Josef A. Jungmann (eds.), Kyriakon: Festschrift J. Quasten (Munich: Aschendorff, 1970), 1, pp. 18-35; and Andrew McGowan, 'Eating People: Accusations of Cannibalism Against Christians in the Second Century', Journal of Early Christian Studies 2 (1994), 413-442. 
(In the end, while he still lived and could see, they gave his blood to drink to his dear brother Lucat, for whose safety he kept praying, drawing upon himself all the hatred for their misdeeds. And they had twenty of his most favorite captains feed on him, tearing his flesh with their teeth and swallowing the morsels. The rest of his body, and the inner parts, when he was dead, were boiled and given to others of his followers to eat. $)^{30}$

During the Wars of Religion, Protestants accused Catholics of cannibalism because of their belief in transubstantiation, and Catholics sold the dissevered limbs of Huguenots in Paris and Lyon after the St. Bartholemew's Day Massacre (1572). ${ }^{31}$ In Flavia, it is Apollonius who has slaughtered infants over the fire, as he himself freely admits (I.1.256-265). More important, it is Domitian who, under the direction of Apollonius, sacrifices the young Flavians and prepares a Thyestian feast for his brother. 'I dread Thyestes' dish, and the sacred feast of the brothers' ('Ollam Thyestæ vereror, \& fratrum dapes'), moan the chorus (5.9.1056). Thus Flavia not only asserts the antiquity of the Church's insistence that the bread and wine are the flesh and blood of Christ; it unleashes all the anxieties hovering over the ritual practices of sacrifice, communal meals, and burial.

If Christ's real presence in the Eucharist is one of the key mysteries of Flavia, the invisible operations of grace on the human spirit is another. Frustrated by his inability to shake the resolve of his nephews, Domitian prepares to throw them on their funeral pyres, but Apollonius intervenes in order to test their faith in the guise of John (yet another spectacular stage transformation enacted by the Protean sorcerer). The boys' stout resistance to John's specious arguments, which, among other things, urge a mere outward conformity with the state religion, reveal that they have sharpened their ability to 'discern spirits' and will prove 'faithful vntil death' (Rev. 2:10). As the boys use their momentary reprieve to dash down a statue of Jupiter, they experience an effluence of grace:

$30 \quad$ Michel de Montaigne, 'Courdise mere de la cruauté', bk. 2, ch. 27 of Les Essais de Michel de Montaigne, ed. Pierre Villey, 2 vols. (Paris: Presses Universitaires de France, 1978), 1, p. 701, transl. Donald M. Frame, The Complete Essays of Montaigne (Stanford: Stanford University Press, 1957), p. 530.

31 Natalie Zemon Davis, Society and Culture in Early Modern France (Stanford: Stanford University Press, 1975), p. 324. 
VESP. Quis hic in imis ossibus serpit calor Domiti?

Dom. Medullas mollis afflatu levi

Emulcet aura: pectus inspirat Deus.

Agnoscis almi numinis sensus pios?

VESP. Indicia recolo. Numen ô numen bonum!

Excipere plenos, frater afflatus licet?

DOM. Licet, libetq́ue: pande sis omnes sinus

Auræ influenti; funde taciturnas preces.

VESP. Nescio quid instet: entheus, solito amplior,

Insinuat ardor: magna sunt sensu mala,

Quæ lenit, antè providus tantò, Deus.

v. $6.532-542$

(VESP. What is this grace that creeps into my deepest bones, Domitian?

DOM. A soft breeze touches my marrow with its gentle breath. God breathes on my heart. Do you recognize the holy touch of his nurturing divinity!

VESP. I recognize the signs. Divinity, oh good divinity! Brother, is it possible to receive his full inspiration?

Dom. It is possible, and it is pleasing. Come, open your whole breast to the breeze that influences it; pray silently.

VESP. Something is about to happen. A divinely inspiring warmth greater than usual enters me. There are evils grievous to feel that God alleviates, foreseeing them far in advance.)

Key words in this passage evoke Roman values and pagan expectations only to overwrite them. We might contrast Andromache's chill when she thinks she is confronted by a divine messenger in Vergil's Aeneid: 'the warmth forsook her limbs' ('calor ossa reliquit', III.308). ${ }^{32}$ Or we might contrast Thebes' longing for a soothing breeze in Seneca's Oedipus: 'No soft breeze with its cool breath relieves our breasts that pant with heat, no gentle Zephyrs blow' ('Non aura gelido lenis afflatus fovet | anhela flammis corda, non Zephyri leves | spirant' Oed. 37-38). ${ }^{33}$ Or we might even recall the ardor with which Vulteius inspires Caesar's men to their last stand in Lucan's Pharsalia:

32 Virgil, transl. H. Rushton Fairclough, rev. ed., 2 vols., Loeb Classic Library (Cambridge: Harvard University Press, 1932).

33 Seneca, Tragedies, transl. Frank Justus Miller, 2 vols., Loeb Classical Library (Cambridge: Harvard University Press, 1917). 


\section{'Agnoscere solis}

Permissum, quos iam tangit vicinia fati, Victorosque dei celent, ut vivere durent, Felix esse mori.' Sic cunctas sustulit ardor Mobilium mentes iuvenum.

$$
\text { IV.517-522 }
$$

(None but those whom the approach of death already over-shadows are suffered to know that death is a blessing; from those who have life before them, the gods conceal this, in order that they may go on living.' By his words the hearts of all the warriors were changed, and swelled with martial ardor. $)^{34}$

In Stefonio, such classical diction (calor, afflatus, ardor) is deployed to describe the experience of grace, which the Jesuit Claude Delidel defines as 'an inspiration, a knowledge, a supernatural light that God pours into our understanding ... a divine enticement, a celestial fire that takes hold of our heart and which inflames a sacred desire to perform faithfully what God asks of our liberty' ('une inspiration, une connaissance, une lumière surnautrelle que Dieu verse dans notre entendement ... un attrait divin, un feu céleste qui se prend à notre cœur, et qui l' enflamme d'un sain désir d' exécuter fidèlement ce que Dieu demande de notre liberté).$^{35}$ In Flavia, this celestial fire manifests itself in the countenances of the boys as an intimation of the divine. When asked how the young Flavians endured their deaths, a messenger reports:

NVNC. Quo nemo vitam. Certus æternæ spei Stetit acer animus: frontis excelsæ color, Et roseus, ille fulgor in vultu manet Lætior; \& ille pectore ex imo decor Effloret, index certus ingenuæ facis: Et in ore, mentis hospes, existit DEVS. Neges perire puberes: nasci putes.

$$
\text { v.9.961-967 }
$$

34 Lucan, Pharsalia, trans. J.D. Duff, Loeb Classical Library (Cambridge: Harvard University Press, 1928).

35 Claude Delidel, La Théologie des Saints (Paris: J. Henault, 1668), pp. 23, 339. David Clarke, Pierre Corneille: Poetics and Political Drama under Louis XIII (Cambridge and New York: Cambridge University Press, 1992) discusses these passages on p. 246. 
(HERALD. As no man endures even life. Their fierce spirit, secure in eternal hope, stood firm. The complexion of their haughty brow and that rosy glow on their face remained full of joy; and that beauty from their inmost heart bloomed up, a sure indication of their noble passion; and in their face appeared a visitor to their mind: God. You would not say the boys were dying; you would think they were being born.)

According to Gilles Deleuze, the 'essence of the Baroque entails neither falling into nor emerging from illusion, but rather realizing something in illusion itself, or of tying it to a spiritual presence that endows its spaces and fragments with a collective unity.' ${ }^{36}$ The spiritual presence that unifies Flavia's involved theatrical architecture is Christ in his three-fold function as creator, as mediator, and Christ the judge.

\section{Flavia as Baroque Drama}

Since Jacob Burckhardt and Wilhelm Lübke pioneered the use of the term baroque to describe the style of art and architecture that succeeded renaissance classicism and Heinrich Wölfflin suggested that the term might be applied to the period's poetry and music as well, critics have employed the term in two broad senses: to refer to a mode of feeling and expression that recurs throughout history, alternating with the purity, restraint, and concentration of classicism; or to refer to a 'decadent' or 'hybrid' style of art that emerged in late sixteenth century when, as Benedetto Croce would have it, the CounterReformation papacy, having collapsed religion into politics, developed a new idiom to project its power in symbolic form, or when, as Peter Davidson prefers, the diaspora of European civilization that commenced with the voyages of discovery led to a 'system of international discourses, a "way of proceeding," a symbolic language' that transcended national and confessional lines, finding its most characteristic expression where colonists and missionaries encountered alien cultures. ${ }^{37}$ It is no accident that the Jesuits, whether centered in

36 Gilles Deleuze, The Fold: Leibniz and the Baroque, transl. Tom Conley (Minneapolis and London: University of Minneapolis Press, 1993), p. 33. 
Rome or circulating among in their missions, whether resented as obstacles to Italian unification or lauded as trans-national agents, figure large in Croce's indictment and Davidson's valorization of the baroque.

For the purposes of this essay, I adopt Davidson's characterization of a 'universal baroque' that, if able to recur through history, nevertheless took a particular form in the late sixteenth and seventeenth centuries, not least because of the efforts of the Jesuits. Baroque art, as Davidson defines it, will always be grounded 'in reference to antiquities' - not antiquity conceived as a monolithic inheritance but antiquities conceived as a cultural plurality. It is 'so much in love with the remote and exotic that it draws strangeness unto itself.' It embraces hybridity and eclecticism. It often embarrasses us by its refusal to ignore the sensuous, and it is unabashed in its desire to provoke wonder. ${ }^{38}$ If it 'establishes a total unity or a unity of the arts' as Deleuze observes, 'it does so first of all in extension, each art tending to be prolonged and even to be prolonged into the next art, which exceeds the one before. ${ }^{39}$ Although baroque art may not always be original, it is never at a loss; it has a response to every occasion, and therefore the festival is its most characteristic expression. A product of the Reformation and Counter-Reformation, it treats heresy and religious controversy as givens of the world we live in.

Davidson could have been writing with Flavia in mind, for the play evokes a multiplicity of ancient cultures and religions originating in Greece, Babylon, India, Egypt, Ethiopia, Judea, and Rome itself. If it expects its audience to reject those elements of pagan civilization associated with the standard of Lucifer, it does not ask them to turn their backs on antiquity, for it frankly concedes that the grandeur of papal Rome is founded on the majestic ruins of imperial Rome. By means of its sumptuous costumes-probably based on Justus Lipsius's treatise of 1596, De militia Romana (On the Roman Army) —and

ester University Press, 2007), ch. 1, qt. at p. 1; and Helen Hills, 'The Baroque: The Grit in the Oyster of Art History', in Helen Hills (ed.), Rethinking the Baroque (Farnham, England and Burlington, vT: Ashgate, 2011), pp. 11-36. For the accounts referred to, see Jacob Burckhardt, Der Cicerone (Basel: Schweighauser'sche Verlagsbuchhanglung, 1855); Wilhelm Lübke, Geschichte der Architektur von den Ältesten Zeiten bis auf die Gegenwart (Cologne: E.A. Seemann, 1858); Heinrich Wölfflin, Renaissance and Baroque [1888], transl. K. Simon (London: Collins, 1964); and Benedetto Croce, Storia della età barocca in Italia: Pensiero e Letteratura Vita Morale (Bari: Laterza, 1929).

38 Davidson, Universal Baroque, pp. 12-19, qts. at p. 12. Davidson is especially influenced by two fine earlier studies, Eugenio d'Ors, Du baroque, transl. Agathe Rouart-Valéry (Paris: Gallimard, 1936); and Giovani Careri, Baroques, transl. Alexandra Bonfante-Warren (Princeton and Oxford: Princeton University Press, 2003). 
its elaborate reconstructions of Roman ceremonies, military displays, pyrrhic dances, and figured maze dances, Flavia creates a theatrical palimpsest in which the contemporary is written over the ancient - or the ancient over the contemporary - in the moment of performance. An instance of this effect occurs in the choral ode that closes Act 2, when the first hemi-chorus of Christians prays for the prosperity of Clemens's rule:

Dive, si sævos cohibes tyrannos,

Mente si mundum moderaris æquâ,

Regna CLEMENTIS, geminumq́ue fratrum

Stemma secundes.

II.7.1212-1215

(God, if you hold fierce tyrants in check, if you command the world with a fair mind, favor Clemens's rule and the double crown of the brothers.)

The devout wish of the chorus will, of course, be cruelly disappointed by the savage fury of a tyrant whom God does not hold in check, but the chorus must have sounded, too, like a prayer for the prosperity of Pope Clement viII and his Aldobrandini nephews. ${ }^{40}$ Although the play identifies itself as a tragedy, it might as accurately be called a theatrical hybrid or bricolage: part autos sacramentales, part Roman festival, part Senecan revenge tragedy. Its initial performance took a full ten hours because each of these genres displays a drive to extend itself, to break out of its frame, to overtop its rivals.

As Flavia revisits the controversies of the early Church in the context of a papal jubilee, it suggests that there is nothing unprecedented about the Counter-Reformation: the true Church has ever been defined against heresy and schism. By far the most striking way in which Flavia implicitly controverts the Lutherans is by dramatizing the historical conditions from which the book of Revelation emerged. In his 1522 Preface, Martin Luther (1483-1546) considered excluding Revelation from the New Testament as 'neither apostolic nor prophetic' because 'Christ is not taught or known in it'.11 But by the time he revised his preface, he was prepared to argue that, since the book was 'intended as a revelation of things that are to happen in the future, and especially the tribulations and disaster of the Church', the 'events and disasters that have come upon the Church before now' could be used as an interpretive key

$40 \quad$ Villoslada, Storia del Collegio Romano, p. 164.

41 Martin Luther, 'Preface to the Revelation of St. John' (1522), in Works of Martin Luther (Philadelphia: Muhlenberg Press, 1932), 6, pp. 488-489. 
to its obscure prophecies. ${ }^{42}$ This new interpretation of Revelation became a powerful weapon in the Lutheran assault on Pontifical Rome, for it identified the papacy as the historical instantiation of Antichrist. Indeed, the structural principle of the Magdeburg Centuries has been identified by one commentator as 'the hidden Antichrist, the public Antichrist, the unmasked Antichrist' ('l' Antéchrist caché, l'Antéchrist publique, l' Antéchrist devoilé'). ${ }^{43}$ It seeks to demonstrate that, from the death of the last of the Apostles to the restoration of the true religion by Luther, the Church had been misled by the Roman Antichrist.

By the time Flavia was performed in 1600, however, the Jesuits Francisco Ribera and Cardinal Robert Bellarmine had pioneered a historico-critical approach to Revelation that blunted the edge of the Lutheran exegetical tradition, for they denied that Revelation foretold history up to 1600 and demonstrated with great erudition that there was no sound reason to identify the papacy with Antichrist: Revelation was a product of its early Roman, Jewish, and Christian context, and the fulfillment of any prophecies it might contain in its final chapters lay in the future. ${ }^{44}$ Two of Bellarmine's specific arguments shed abundant light on Flavia. The first is that, according to John 2:22, the Pope cannot be identified with Antichrist because, whereas Antichrist 'denieth the Father and the Sonne', the Vicar of Christ acknowledges and serves them. And the second is that, although he may have had forerunners in the time of the apostle John, such as Nero and Simon Magus, Antichrist himself will not arrive until the Roman Empire has fallen, a historical event reserved for the future. ${ }^{45}$ The frustration that reformers felt with such interpretations - which retain wide

42 Luther, 'Preface to the Revelation of St. John' (1545), in Works, 6, p. 481.

43 F. Gilmont, s.v. 'Flacius Illyricus', in Dictionaire d'histoire et de geographie ecclésiastique (Paris: Letouzey et Ane, 1912-), vol. 17, col. 321.

44 For a brief introduction to these and rival accounts of Revelation, see Bernard McGinn, 'Revelation', in Robert Alter and Frank Kermode (eds.), The Literary Guide to the Bible (Cambridge, MA: Belknap Press of Harvard University Press, 1987), pp. 523-541. For more exhaustive guides, see D.E. Aune, Revelation 1-5; Revelation 6-16; and Revelation 17-22, World Biblical Commentary 52a, b, c (Dallas: World Books, 1997-1998); and Pierre Prigent Commentary on the Apocalypse of St. John, transl. Wendy Pradels (Tübingen: Mohr Siebeck, 2004). On Bellarmine more generally, see E.A. Ryan, S.J., The Historical Scholarship of Saint Bellarmine (New York: Fordham University Press, 1936); Aimé Richardt, Saint Robert Bellarmin, 1542-1621: Le défenseur de la foi (Paris: François-Xavier de Guibert, 2004); Stefania Tutino, Empire of Souls: Robert Bellarmine and the Christian Commonwealth (Oxford: Oxford University Press, 2010).

45 For Bellarmine's arguments and a Protestant response, see Brightman, A Revelation of the Apocalyps, pp. 497, 507, $5^{22}$ [mispaginated 514]-529. 
currency among modern scholars of Revelation - can be measured by their swift response. Thomas Brightman inserted a hundred page refutation of Bellarmine into his commentary on Revelation (1611), and in his own commentary on Revelation (1618, English translation 1644), the Calvinist David Pareus (15481622) complained, 'The Jesuites, Antichrists chiefest Soldiers are very ingenious to corrupt, and wrest the plaine Oracles of this Prophesie into a contrary meaning, as if they were not only not to be applied against the Papacy, but also did make for the dignity thereof.' ${ }^{46}$ Although these responses post-date Flavia they suggest the polemical force of Bellarmine's interpretation and of Flavia's dramatic realization. Both the play's introduction of Cerinthus, a denier of Jesus Christ, and its insistence on the continuity of the Roman Empire have the effect of undermining the Protestant identification of the papacy with Antichrist.

When the John of Flavia is asked by his companion Nereus if the grief of the Christian community will find no limit (cf. Rev. 6:10), John responds that it will find one, but the things which God promises us are late in coming (v.9.783784). He then provides a preview of Revelation that unfolds according to Jesuit interpretations of the book. Whereas Apollonius had established a reputation for his prescience about current events, John admits that he can see only distant things. He explains that of the seven storms that threaten Christians, one, Nero's persecution of the Christians, has already raged; although he cannot foretell precisely how the others will manifest themselves, he predicts the destruction of Christians by sword, famine, fire, and wild beasts (Rev. 6:8). His roll-call of martyrs includes some, such as Agnes and Cecilia, whose remains had just been rediscovered in the Roman catacombs. The name of Nereus, whose martyred remains had recently been translated to Cardinal Baronio's titular church, might have been silently added to the roll call by Flavia's Roman audience. John then foretells a time when the Church will dominate Rome and the better part of the globe, erecting a hundred shrines arrayed with Thracian stone and adorned with princely luxury (v.9.828-847). Before he can proceed any farther, however, he is interrupted by a herald bringing news of Domitian's bloody feast, 'With what lament can I bewail the deadly rituals of Kings? | Does Domitian rule Rome, or is it Atreus ruling Corinth?' ('Quo dira Regis sacra ploratu queror? | Romam, an Corinthum, Domitius, an Atreus tenet?', v.9.845846). Thus Flavia cuts John's prophecy short, preempting some of the most contentious chapters of Revelation.

It is a stylized 'fact' that whereas the drama of the Reformation promulgates propaganda, the Jesuit drama, 'conscious of its immovable foundation, is more 
concerned to maintain and defend the ground it already commands than to collect new associates', that whereas the former courts political and ecclesiastical controversies and often satirizes the papacy openly, the latter generally eschews direct polemic against Luther, preferring to explore themes drawn from the bible and the deeper recesses of history. ${ }^{47}$ If Flavia does nothing to explode this contrast, it nevertheless admonishes us not to assume too quickly that the controversies of the first centuries of the Church are of merely historical or pedagogical interest, or that setting a scriptural text in context is a neutral act of historical reconstruction. Jesuit tragedy is founded upon antiquities, not lost among them.

\section{Flavia as a Tragedy of Tyranny and Martyrdom}

A long tradition of criticism has used chapter 13 of Aristotle's Poetics to argue that martyrs cannot be tragic heroes because, as André Dacier put it succinctly in 1692: 'In whatever manner we regard martyrdom, either as a good, or as an evil, it cannot excite either pity or fear; and consequently cannot purge the passions' ('De quelque maniére qu'on regarde le martyre, ou comme un mal ou comme un bien, il ne peut exciter, ny la pitié ny la crainte, \& par consequent il ne purgera pas les passions').$^{48}$ Dacier's judgment is based on Aristotle's advice that a tragic hero be a man 'who on the one hand is not a paragon of virtue and justice and on the other hand does not suffer the change to misfortune because of wickedness or villainy but because of some mistake ( $\left.\dot{\mu} \mu \rho \tau^{\prime} \alpha v\right)$; the philosopher adds that 'virtuous men' should not 'be shown shifting from good fortune to bad, for this is not fearful, and not pitiable either, but morally

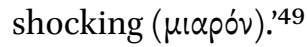

Stefonio's successors at the Collegio Romano-Alessandro Donati and Tarquinio Galluzzi-formulated thoughtful responses to this dismissal of martyrdom as a valid subject of tragedy. An important starting point for their theories is Ludovico Castelvetro's commentary on the Poetics $(1570,1576)$. Castelvetro denies the psychological premise that leads Aristotle to describe the suffering

47 Karl von Reinhardstöttner, 'Zur Geschichte des Jesuitendramas in München', Jahrbuch für Münchener Geschichte 3 (1989), 53-176, quote at p. 59; McCabe, An Introduction to Jesuit Theater, pp. 26-31.

48 André Dacier, La Poétique d'Aristote, traduite en français avec des remarques critiques (Paris: Barbin, 1692), p. 178.

49 See Aristotle, Poetics 1452b31-53a10, transl. in Gerald F. Else, Aristotle's Poetics: The Argument (Cambridge: Harvard University Press, 1967). 
of a virtuous man as 'morally shocking' or 'polluted', maintaining that, even if ancient Greeks responded in this way to the plight of a holy man, there is no reason to assume that Christians will. ${ }^{50}$ The suffering of innocents does not provoke moral scandal, says Castelvetro, because the common people have many ways of retaining their belief in God. They can turn 'their hate against the immediate causes which by God's permissive will had the power to work the holy man's hurt' ('odiando le cagioni prossime alle quali è prossime alle quali è stato permesso di poetere nuocere alla persona santa'). Or they can conclude that the 'holy man has been tried by misfortune so that he may become more perfect, as gold is refined in the fire. Or they may reason that he has been ill-treated because God chose this way to manifest His glory' ('che la persona santa sia tentata con simili disaventure, accioché, sì come l'oro nel fuoco s'affina, così ella nelle tentazione migliori e si faccia più perfetta, or che la persona santa sia così mal trattata perché Dio vuole col suo mal tratamento far rilucere la gloria sua'). ${ }^{51}$ Pietro Sforza Pallavicino, a professor of philosophy and theology at the Collegio Romano, official historian of the Council of Trent (1656-1657), and author of the tragedy Ermenegildo martire (1644), which presented St. Hermenigildus as a martyr to Arianism, observed that the Jesuit theater had proven the justice of Castelvetro's claim: Martyr plays could excite the most tender devotion in every class of spectator, drawing tears from great intellects and melting the eyes of the obdurate. ${ }^{52}$

That martyr dramas might not qualify as tragedies because death marks a change for the better in Christian belief occurred to early modern critics (as we have seen from Dacier) but has been even more forcefully stated in the twentieth century. "The Christian hero has the card of immortality and beatitude with which he can trump the last tricks of his opponents, Paganism and Death', says Martin Jarrett-Kerr. 'Heads may be severed from bodies, but there is no suffering: what seems to be agony is unreal because it is willed, not undergone - the victim remains in control. ${ }^{53}$ Alessandro Donati's answer to

50 Tarquinio Galluzzi, Rinovazione dell'antica tragedia e Difesa del Crispo (Rome: Vatican, 1633), pp. 110-111.

51 Lodovico Castelvetro, Poetica d'Aristotele vulgarizzata e sposta $(1570,1576)$, ed. Werther Romani, 2 vols. (Rome and Bari: Gius. Laterza \& Figli, 1978-1979), 1, pp. 360-363, transl. in Castelvetro on the Art of Poetry: An Abridged Translation, transl. A. Bongiorno (Binghamton, NY: Medieval and Renaissance Texts and Studies, 1984), p. 163.

$5^{2}$ Sforza Pallavicino, Ermenegildo martire: Tragedia recitata da' Giouani del Seminario Romano ... Con un breue discorso in fine (Rome: Gli Eredi del Corbelletti, 1644), p. 145.

53 Martin Jarrett-Kerr, 'Calderón and the Imperialism of Belief', in Studies in Literature and Belief (London: Rockliff, 1954), pp. 38-63 at p. 62. 
such objections is that the serenity of the martyr, which is an extraordinary result of his free will and the gift of grace, is not easy for audiences to identify with. Instead, they wonder at it, fearing what exceeds their faculties, and in the meantime the horror of the physical punishment perturbs their souls. Even if a tyrant on stage stirs up affections such as hate or anger that are contrary to pity and fear, these can co-exist with the tragic passions. Whereas Alessandro Piccolomini had suggested in 1575 that the affective capacity of souls was finite and that when audiences felt hatred or loathing for a malefactor they might be less able to feel pity for his victim, Donati denies the premise. ${ }^{54}$ We might recall the access of grace that the young Domitian and Vespasian experience in the moments before their death. Even though they face death unperturbed, we cannot behold their death without admiring their ethos and mourning its extinction. Their indifference to death is sublime; it at once defeats our comprehension and makes us aware that there must be some ineffable force, be it the greatness of the human spirit or the efficacy of divine grace, that can muster such a proud disregard of the carnal.

Characters of such exemplary virtue are not, Donati insists, a modern invention. Hippolytus cultivates his chastity, Alcestis dies to prolong the life of her husband, and the Hercules of Seneca's Hercules Oetaeus is even carried to the heavens by clouds once his pyre is lighted. If the ancients could applaud such heroes, asks Donati, why shouldn't Catholics dramatize the suffering of martyrs? He instances Macaria, who dies for her city with heroic resolution in Euripides' Heracleidai (The Children of Heracles): 'Lead me to the place where it seems good that my body should be killed and garlanded and consecrated to the goddess! Defeat the enemy! For my life is at your disposal, full willingly, and I offer to be put to death on my brothers' behalf and on my own. For, mark it well, by not clinging to my life I have made a most splendid discovery, how to die with glory!' (ll. 528-534). ${ }^{55}$

Yet it is Tarquinio Galluzzi who responds most courageously and creatively to chapter 13 of the Poetics, for he undertakes to do nothing less that expose Aristotle's complicity with tyranny. In his 1633 Rinovazione dell'antica tragedia (Renewal of Ancient Tragedy), dedicated to cardinal Francesco Barberini, a former pupil at the Collegio Romano, the nephew of Pope Urban VIII, and a patron of the arts, Galluzzi maintains that the font and origin of tragedy was the Athenians' love of liberty and hatred of tyranny. The basis of his claim is

\footnotetext{
54 Alessandro Donati, Ars poetica siue Institutionum artis poeticae libri tres [Rome, 1631] (Cologne: Ioannem Kinchium, 1633), pp. 167-170; Pallavicino, Ermenegildo, 144-145.

55 Euripides, Volume 2: Children of Heracles: Hippolytus: Andromache: Hecuba, ed. and transl. David Kovacs, Loeb Classical Library (Cambridge, MA: Harvard University Press, 1995).
} 
the Minos, a dialogue that classicists now generally ascribe not to Plato himself but to a pupil or follower. The ostensible subject of the dialogue is the nature of law, but the conversation turns to tragedy when Socrates says that Minos was a great law-giver. ${ }^{56}$ Then why, objects his companion, is he reputed to have been uneducated and harsh-tempered? Minos's mistake, says Socrates, was in waging war on Athens, a city that has poets of every kind, especially tragic ones: 'Now tragedy is a thing of ancient standing here; it did not begin, as people suppose, from Thespis or Phrynicus, but if you will reflect, you will find it a very ancient tradition of our city. Tragedy is the most popularly delightful and soul-enthralling branch of poetry; in it, accordingly, we get Minos on the rack of verse, and thus avenge ourselves for that tribute which he compelled us to pay. 57 The most poetic accounts, which persisted despite the denials of the Cretans and Aristotle alike, held that every nine years the Athenians were compelled to send seven young men and women to Crete to be destroyed by the Minotaur or to wander to their deaths in the labyrinth. 'And verily it seems to be a grievous thing for a man to be at enmity with a city which has a language and literature,' observes Plutarch in his Life of Theseus (26). 'For Minos was always abused and reviled in the Attic theatres; and it did not avail him either that Hesiod called him 'most royal', or that Homer styled him 'a confident of Zeus', but the tragic poets prevailed, and from platform and stage, showered obloquy down upon him, as a man of cruelty and violence. ${ }^{58}$

Galluzzi supposes that Athens must have celebrated the return of Theseus from his encounter with the Minotaur with festivals that included 'some figured dances with interweavings, entanglements, and disentanglements both artful and wondrous, which imitated the intricate paths of the Labyrinth' ('alcuni balli ordinò, e dispose con intrecciamenti, viluppi, e suiluppi artifiziosi, e mirabili, che rappresentauano le intricate vie del Laberinto'). 'From such festivals,' speculates Galluzzi, 'the first tragedy against Minos must have been born and come to light, permitting the city to behold itself freed from his tyranny' ('Trà le quali feste è necessario, che nascesse, e venisse in luce la prima Tragedia contro Minosse, da che la Città vedeuarsi libera dalla Tirannide de lui'). ${ }^{59}$ Even in later centuries, Galluzzi speculates, tragedy must have retained a vestigial memory of this origin in the movements of its chorus, whose 'strophes and antistrophes

\footnotetext{
56 Delrío, Syntagma tragoediae latinae, p. 20.

57 Plato, Minos, 320d-321a. In Plato, vol. 8. transl. W.R.M. Lamb, Loeb Classical Library (Cambridge, MA: Harvard University Press, 1955).

58 Plutarch's Lives, trans. Bernadotte Perrin, 11 vols., Loeb Classical Library (Cambridge: Harvard University Press, 1917), vol. 1, pp. 31-33. 
had been created by Theseus to commemorate the pathways of the twisting Labyrinth from which he had exited safe and sound' ('strophas illas, atque antistrophas inuentas à Theseo fuisse ad commemorandas flexuosi Labyrinthi vias, ex quibus euaserat sospes') ${ }^{60}$ At its first performance, the dance of Theseus and the Athenian youth had recreated a nightmarish labyrinth that threatened blind wandering and death in order that they might enact their own triumph over tyranny. The prime and ancient end of tragedy, then, was to engender a hatred of tyranny in the soul of the people by making them watch the examples of the cruelty and barbarity of tyrants while cultivating - not least through the chorus - a love of liberty. For at its root, choral dance was a joyous affirmation of freedom. ${ }^{61}$

It would square with what we know of the values of the Athenians to imagine that tragedy had some such beginning, says Galluzzi, for the first public statues that they erected commemorated the bravery of two would-be tyrannicides, Harmodius and Aristogeiton, whose unsuccessful attempt to cut down Hippias in 514 BC was remembered as a step toward Athenian democracy. ${ }^{62}$ Phrynicus's tragedy on the Capture of Miletus (511 BC) engendered such excessive grief among the Athenians precisely because it forebode their loss of liberty. But Aristotle could not acknowledge the true end of tragedy because he wrote at a time when the ancient liberty of Greece was extinct. Adapting to his political circumstances, for it would not do to offend Philip of Macedon or Alexander the Great, Aristotle praised tragedies in which persons of middling virtue bring suffering on themselves through some error. Although Aristotle justifies this formula in affective terms, saying that our pity and terror are aroused most effectively if we can identify with those on stage, his ulterior motive is to divert enmity away from tyrants and to use pity and fear to teach his contemporaries prudence and an acceptance of servitude. ${ }^{63}$

Aristotle's ideal is so innovative in the history of Greek tragedy, says Galluzzi, that we ought by rights to distinguish between old and new tragedy. Old tragedy as Galluzzi defines it runs from the time of Theseus, through Thespis and

6o Tarquinio Galluzzi, Tarqvinii Gallutii Sabini e Societate Iesv Virgilianae vindicationes \& commentarij tres de tragoedia, comoedia, elegia (Rome: Alessandro Zannetti, 1621), p. 281.

61 Galluzzi, Rinovazione, p. 37. On the classical origins of labyrinth dances and their revival in the Renaissance, see Thomas M. Greene, 'Labyrinth Dances in the French and English Renaissance', Renaissance Quarterly 54 (2001), 1403-1466.

62 For the place of Harmodius and Aristogeiton in Athenian art, see Michael W. Taylor, The Tyrant Slayers: The Heroic Image in Fifth-Century B.c. Athenian Art and Politics (New York: Arno Press, 1981).

63 Galluzzi, Rinovazione, pp. $5^{6-58 .}$ 
Phrynicus (who wrote tragedies on Alcestis, the daughters of Danaus, and Tantalus - none of them middling characters), and onto Euripides. Indeed, Euripides is the exemplary old-style tragedian, one who is not afraid to depict the tyranny of Minos in his lost Cretenses (Cretans) or the suffering of a pure young man in his Hippolytus. The new tragedy is a critical invention of Aristotle, an invention that may appeal to the example of Sophocles for sanction but that became politically necessary only during the reign of Alexander. Although Galluzzi recognizes that the Old Testament can furnish characters who meet all the requirements of an Aristotelean hero who falls into misfortune by committing an error, he urges his contemporaries to follow the Minos when determining the ends of tragedy and the persons who should be introduced to the stage and to obey the Poetics only when deciding on other elements of dramatic craft. For to Galluzzi's mind, the Minos sanctions plays that inspire a hatred of tyranny while confirming spectators in their faith, as they watch inhuman cruelties inflicted on faithful martyrs who die 'with steadfast and happy countenance, with intrepid heart, and often with unheard of wonders of nature' ('con fermo e con lieto volto, con cuore intrepido, e spesso con accompagnamento d'inusitati prodigii'). ${ }^{64}$

If Donati helps us understand how the stalwart deaths of the young Domitian and Vespasian can be dramatic, Galluzzi explains why Jesuit tragedies are so invested in displaying the insatiable cruelty of tyrants, which is not content with simple extermination. Domitian will not rest content until he has witnessed the anguish on this brother's face:

Cernere juvabit. Ora natorum pater

Cùm abscissa cernet, ore quos motus dabit?

Quos voce quetus? ingeram luctum improbe:

Spectabo vultus: exigam fructum mei

Sceleris: perirent cuncta, nisi moestum patrem

Natis ademptis cernerem: nisi vulneris

Imprimeret altum pectori sensum dolor.

V.10.1068-1074

(It will please me to see it. When the father sees his sons' severed head, what expressions will he display on his face? What laments will he offer with his voice? I will wickedly add to his grief. I will look upon his face. I will demand the fruit of my wickedness. Everything would be ruined if I

64 Galluzzi, Rinovazione, esp. pp. 52-53,59-63, 66; quotation at p. 62 . 
could not see the father in grief now that his sons have been taken away, if the pain of that wound were not impressing the sensation deep in his heart.)

Having issued orders to his soldiers to dislodge and destroy the Christian community of Rome, Domitian menaces the Christians with all the torments that we find enumerated in the letters of the early Christians (v.10.1081-1082). Domitian then confronts his brother. Playing a part-for there are no more theatrical characters in Jesuit tragedies than tyrants, false counselors, and magiciansthe emperor begs his forgiveness, pleading that he was dragged along by an unseeing rage (v.10.1098-1099). Although Flavius Clemens is prepared to forgive the torture and indignity he has suffered, he will not drink a libation to Athena, refuses the robes and crown of rule proffered to him, and clings to his chains:

Vinculus necti mihi

Dulce, \& decorum est: Vincla sic CHRISTVS DEvs

Gessit: sed insons. Laude me tantâ frui

Permitte: CHRISTI, frater, imitabor decus.

V.10.1132-1135

(It is sweet and proper for chains to be tied upon me. Thus Christ the Lord wore chains, though innocent. Allow me to enjoy so great an honor: I will imitate the glory of Christ, brother.)

Ignoring his brother's imitatio Christi, the emperor removes his chains, dresses him in a fine mantle, and asks if he would like to see his sons. By the end of the scene, we will be certain, if we are not already, that the emperor has been playing an elaborate charade and would never have reconciled with his brother, for the libation cup is filled to the brim with the blood of the slaughtered boys, a dark parody of the Christian Eucharist.

Implying that the sons will be summoned alive, the emperor instead presents their severed heads, then poses the question that Atreus asks his brother Thyestes in a similar situation:

Filios noscis, pater?

Agnosce vultus; fruere; complexum expedi:

Saturare: vissus pasce: contrecta duos.

$$
\text { v.10.1148-1150 }
$$


(Do you know your sons, father? Recognize their faces. Take pleasure in them. Offer an embrace. Be satisfied. Feast on the sight. Touch them both.)

Whether such gory spectacles had a legitimate place on stage was a matter of critical debate in the seventeenth century. Those who wished to banish them appealed to Horace's Ars poetica, where, after admitting that what finds entrance through the eye more vividly stirs the mind, he nevertheless insists that Medea's butchery of her boys and Atreus's preparation of human flesh as food are not fit to be staged: They should only be narrated by an actor (1l. 180188). But the professors at the Collegio Romano bridled at such restrictions. Misreading a passage from Philostratus's Life in which the sage defends the Brahmins's use of illusions to add dignity to their religion by comparing it to Aeschylus's use of spectacle in his tragedies, they observe that before Aeschylus invented the messenger's speech, the ancient Greeks used to kill men on stage for the sake of realism, and they add more accurately that the Romans revived the practice of theatrical bloodshed, castrating criminals cast in the role of Atys and burning alive those cast as Hercules. ${ }^{65}$ Whatever Horace's tastes may have been, says Donati, they were not those of his fellow Romans who gathered to watch bloody ludi. Far from shunning the troubling comparison of tragedy with gladiatorial exhibitions - a comparison that has a long and equivocal history in accounts of tragic pleasure-Donati embraces it because he maintains that the more horrible the evils in tragedies, the more likely we are to feel wonder (admiratio). He extols the sublime effect of a violence that exceeds all measure. ${ }^{66}$

In Flavia, the effect of the bloody spectacle is first registered by Flavius Clemens, whose somatic response - tears, slumped head, breaths drawn from deep in his chest - are enumerated with relish by the emperor as indices of psychological torment. This is one of many scenes in which Stefonio writes in a Senecan vein. But Flavius Clemens does not waver from his faith, and the emperor orders that his head be stricken off in plain sight of the audience. It is hard not to be reminded of Walter Benjamin's observation that in the Trauerspiel characters die not 'not for the sake of immortality' but 'for the sake of the corpse', the 'pre-eminent emblematic property' of baroque tragedy ${ }^{67}$

65 Galluzzi, Vindicationes, pp. 306-309; Donati, Ars poetica, p. 150.

66 Donati, Ars poetica, pp. 150-151, 163.

67 Walter Benjamin, The Origin of German Tragic Drama, transl. John Osborne (London: Verso, 1998), pp. 217-218. But on the short-comings of Benjamin's account, see Blair Hoxby, 'The Function of Allegory in Baroque Tragic Drama: What Benjamin Got Wrong', in Brenda 
Apollonius and his apostle Damis then gather up all three heads so that they might play a similar charade with John.

Saddened but not bewildered, John utters a series of apostrophes:

O dulce cari capitis exuvium hoc mihi!

O car Iuvenum spolia, Romanis mihi

Potiora Regnis! ite nunc comites fugæ,

Sic ite mecum farcinæ pondus leve.

O me beatum munere hostili senem!

V.10.1225-1229

(O the spoils of this beloved head, so dear to me! O beloved spoils of the Youths, better to me than the kingdom of Rome! Come now, as companions of exile, come with me, a light burden in my bag. $\mathrm{O}$ what a blessed old man I am in this gift from my enemy!)

By addressing the heads as spoils, John overwrites Rome's traditional language of war with a new gospel so revolutionary that it can express itself only in paradox. He also provides an apostolic provenance for the veneration of relics, another practice that Protestants depicted as idolatry. ${ }^{68}$ The audience of Flavia would have been well primed for this transvaluation of values.

For in 1597, Cardinal Baronio had furnished a Christian triumph for the relics of the Roman Saints Domitilla, Nereus, and Achilleus, which had originally been buried in the catacombs before being brought in 1228 to $S$. Adriano on the Roman Forum. ${ }^{69}$ Two of these saints appear in Flavia. Domitilla, whose history was published in 1597 by Baronio's collaborator Antonio Gallonio, is the Flavian maiden celebrated by the first hemi-chorus in Act $1:^{70}$

Machowsky (ed.), Thinking Allegory Otherwise (Stanford: Stanford University Press, 2010), pp. $87-116$.

68 See, for example, Brightman, A Revelation of the Apocalyps, p. 510.

69 The chief description of the process is provided in Caesare Baronio, Martyrologium Romanum (Venice: Haeredes Ioannis Guerilij, 1630), May 12, notes $283 \mathrm{ff}$. My summary and interpretation relies heavily on Richard Krautheimer, 'A Christian Triumph in 1597', in Douglas Fraser, Howard Hibbard, and Milton J. Lewine (eds.), Essays in the History of Art Presented to Rudolf Wittkower (London: Phaidon, 1967). On Baronio's treatment of Rome as a sacred landscape, see also Simon Ditchfield, 'Reading Rome as a Sacred Landscape, c. 1585-1635', in Will Coster and Andrew Spicer (eds.), Sacred Space in Early Modern Europe (Cambridge and New York: Cambridge University Press, 2005), esp. pp. 171-178.

70 Antonio Gallonio, Historia della vita e martiro di gloriosi santi Flavia Domitilla vergine (1597); see Fumaroli, Héros et Orateurs, p. 147. 
Hæc tecta, fœlix prole fœlici, tenet

DOMITILLA mater: neptis hîc CHRISTO placet,

DOMITILLA virgo: \&, vera si rumor ferit

Huc remeat hodie Caesarum folix parens,

CLEMENS, decoræ purpuræ æternum decus.

I. $4.819-823$

(Domitilla the mother, fortunate in her offspring, inhabits this house: here her granddaughter, Domitilla the maiden, is pleasing to Christ, and if rumor brings truth, to this place today the fortunate father of the caesars, Clemens, returns, eternal glory of glorious rank.)

And Nereus is the interlocutor of John the Evangelist in Act 5, the Christian who solicits John's precis of Revelation, including the roll call of martyrs that Nereus himself would join. Baronio's procession of 1597 moved with these relics from $\mathrm{S}$. Adriano to the Gesù, where an altar was prepared in front of the church, and thence to the Capitoline Hill, passing between the Dioscuri and stopping at the statue of Marcus Aurelius. It processed under the arches of Septimius Severus (whose wife commissioned Philostratus's Life of Apollonius), Titus, and Constantine, following the Via Sacra to Baronio's title church s.s. Nereo ed Achilleo, where temporary honorific arches displayed the trophies of the martyrs. Inscriptions along the route explained the ideological program of the ceremony. The first claimed that Domitilla, by legend the cousin of the young caesars killed in Flavia, had cleansed the Capitol of the cult of daemons. At the Arch of Septimius, the Senate and the People of Rome declared that the martyrs had brought the peace of Christianity to the Republic and glory to Rome through their sacrifice. The Arch of Titus observed that if that emperor had avenged the death of Christ with the destruction of Jerusalem, Domitilla had avenged it more gloriously by shedding her own blood. The Arch of Constantine pronounced that, although Roman emperors had celebrated their victories over subject peoples along the Via Sacra, these martyrs had triumphed over the triumphators. Domitilla had brought greater glory to Rome through her renunciation of life and empire than the Imperial family and the twelve Caesars had by ruling. A book of poems written for the occasion, chiefly by students at the Collegio Romano, emphasized the romanitas of the martyrs, the glory that their blood had brought to Rome, their paradoxical triumph over worldly glory, and their defeat of paganism.

If the young caesars of Flavia bring greater glory to Rome by renouncing life and empire than by ruling, John will play a more pivotal role in history as a prophet than Apollonius will as a trusted adviser to the emperors of Rome. In 
their parting exchange, John chides his rival that his arts can preserve him only to be punished by God; Apollonius responds that he will turn John over to his own kings for punishment; John counters that 'the vengeance that comes at last comes not too late' ('non est sera, quæ ferò venit / Vindicta', V.10.1234-1235); and Apollonius dismisses him with the words, 'You sing an old and tired song' ('Tritum carmen antiquum canis', v.10.1235). According to the logic of Senecan revenge tragedy, John's 'old and tired song' is the hapless appeal to divine justice with which the impotent must always content themselves in this world. What Apollonius cannot foresee is the new canticle that John will sound on the Isle of Patmos:

And when he had opened the booke, the foure beastes and the foure and twentie seniors fel before the Lambe, hauing euery one of them harpes, and golden vials ful of odours, which are the praiers of sainctes: and they sang a new canticle, saying, Thou art worthie o Lord to take the booke, and to open the seales thereof; because thou wast slaine, and hast redeemed vs to God in thy bloud out of euery tribe and tonge and people and nation, and hast made vs to our God a kingdom and priestes, and we shal reign vpon the earth. (Rev. 5:8-10)

\section{Flavia's Baroque Folds}

I have analyzed Flavia as a sacred representation, as a baroque drama, and as a tragedy. How are these aspects of the work related? I would like to start with the middle term, baroque. In the useful formulation of Deleuze,

[ $t$ ]he Baroque refers not to an essence but rather to an operative function, to a trait. It endlessly produces. It does not invent things: there are all kinds of folds coming from the East, Greek, Roman, Romanesque, Gothic, Classical folds ... Yet the Baroque trait twists and turns its folds, pushing them to infinity, fold over fold, one upon the other. The Baroque fold unfurls all the way to infinity. First, the Baroque differentiates its folds in two ways, by moving along two infinities, as if infinity were composed of two stages or floors: the pleats of matter, and the folds in the soul. Below, matter is amassed according to a first type of fold, and then organized according to a second type.. .71 
Flavia displays the formal properties that critics from Wölfflin to Deleuze have identified with the baroque. If one can refer to its dramatic architecture, it is no stretch to say that its façade and its interior are independent 'but in such conditions that each of the two terms thrusts the other forward. ${ }^{72}$ Each scene displays a will to spill out of its frame. And its maze dances and military exercises, with their turns and counter-turns, their tying and untying, their dissolutions and their resolutions in momentary epiphanies, brilliantly declare the work's allegiance to the labyrinthine as a principle of organization. What's more, its arrangement of the pleats of matter according to the folds in the soul means that the first line I took through the play, as I followed the play's preoccupation with the nature and identity of Jesus Christ, with the suffering and sacrifice of the Son of God, and with the commemoration of that sacrifice in the Eucharist, runs parallel to the third fold, the play's presentation of a tragic fable of suffering and sacrifice that is intended to train the judgment and exercise the passions of the audience. Put another way, Flavia asks us to see the passion of Christ as a tragedy, to identify the essence of tragedy with pathos, and to interpret the meaning of sacrifice and solemn commemoration through the joint example of the crucifixion and the Eucharist. It asks us to recognize theatrical representation as a form of sacred imitation, and it invites us to understand our own nature as beings at once spiritual and carnal—one of the conundrums that has often been thought to lie at the heart of Attic tragedy - through the hypostatic union of Jesus Christ. As it pursues the parallels between the pleats of matter and the folds of the soul, it establishes a commerce between the profane and the sacred, the carnal and the divine, the immanent and transcendent. It discovers the sublime in the humble and perceives intimations of immortality in inanimate relics. Its resonance is at once mortifying and exulted, mournful and expectant. It exhibits the ambivalence that we associate with classical tragedy, but it localizes the field of encounter between the human and divine, the past and the future, in the body and blood of Jesus Christ. 


\section{Further Reading}

Bloemendal, Jan, and Howard B. Norland (eds.), Neo-Latin Drama and Theatre in Early Modern Europe (Leiden and Boston: Brill, 2013).

Chiabò, Maria, and Federico Doglio (eds.), I Gesuiti e i primordi del teatro barocco in Europa (Rome: Centro studi sul teatro medioevale e rinascimentale, 1995).

Davidson, Peter, The Universal Baroque (Manchester and New York: Manchester University Press, 2007).

Fumaroli, Marc, Héros et orateurs: Rhétoriques et dramaturgie cornéliennes (Genève: Droz, 1996).

Hoxby, Blair, What Was Tragedy? Theory and the Early Modern Canon (Oxford: Oxford University Press, 2015).

McCabe, W.J., An Introduction to Jesuit Tragedy, ed. Louis J. Oldani (St. Louis: Institute of Jesuit Sources, 1983).

O'Malley, John W., et al. (eds.), The Jesuits II: Cultures, Sciences, and the Arts, 1540-1773 (Toronto: University of Toronto Press, 2006). 